\title{
Interaksi Gaya Mengajar dan Konten Matematika sebagai Faktor Penentu Kecemasan Matematika
}

\author{
Imam Kusmaryono ${ }^{*}$ dan Nuhyal Ulia ${ }^{2}$ \\ ${ }^{1 *}$ Program Studi Pendidikan Matematika, Universitas Islam Sultan Agung \\ ${ }^{2}$ Program Studi PGSD, Universitas Islam Sultan Agung \\ Jalan Kaligawe Raya KM 4, Terboyo Kulon, Genuk, Semarang, Jawa Tengah, Indonesia \\ 1*kusmaryono@unissula.ac.id; ${ }^{2}$ nuhyalulia@unissula.ac.id
}

Artikel diterima: 25-11-2019, direvisi: 24-01-2020, diterbitkan: 31-01-2020

\begin{abstract}
Abstrak
Matematika merupakan pelajaran yang tidak banyak disukai orang, yang memancing sikap negatif dan menyebabkan pengalaman kegagalan. Salah satu faktor kegagalan adalah adanya kecemasan. Tujuan utama penelitian ini adalah menyelidiki seberapa besar dampak gaya mengajar guru terhadap kecemasan matematika pada siswa jurusan IPA dan IPS serta menyelidiki adanya interaksi antara konten matematika dan gaya mengajar guru dalam menentukan tingkat kecemasan matematika siswa. Desain penelitian ini menggunakan Ex Post Facto Design. Melalui teknik random sampling diperoleh sampel 30 siswa kelas X-IPA dan 30 siswa kelas X-IPS. Pengumpulan data melalui angket survey yang berisi 30 item kecemasan matematika dimana siswa merespons dengan skala Likert 1-5. Data dianalisis melalui uji statistic Anova dua arah dengan interaksi. Hasil penelitian menunjukkan (1) Gaya mengajar guru dengan Problem Based Learning memiliki dampak yang besar terhadap penurunan kecemasan matematika pada siswa di semua jurusan IPA dan IPS, secara statistik signifikan ( $p$ $<0,05$ ) dan secara praktis signifikan dengan dampak (efek) masing-masing $d=0,84$ dan $d=$ 0,55 , dan (2) Terdapat interaksi yang berarti antara konten matematika dan gaya mengajar guru dalam menentukan tingkat kecemasan matematika dengan signifikasi $(p<0,05)$.

Kata Kunci: gaya mengajar, kecemasan matematika, konten matematika.
\end{abstract}

\section{The Interaction of Teaching Style and Mathematical Content as Determinants of Mathematical Anxiety}

\begin{abstract}
Mathematics is a lesson that is not much liked by people, which provokes a negative attitude and causes the experience of failure. One of the failure factors is anxiety. The main objective of this study is to investigate how much the impact of teacher teaching style on mathematics anxiety in students majoring in Natural Sciences and Social Sciences and investigate the interaction between mathematics content and teacher teaching style in determining the level of student mathematics anxiety. This research design uses Ex Post Facto Design. Through random sampling techniques obtained a sample of 30 students of X-IPA class and 30 students of X-IPS class. Data collection through a survey questionnaire containing 30 items of mathematical anxiety to which students responded with a Likert scale of 1-5. Data were analyzed through two-way Anova statistical tests with interactions. The results showed (1) The teaching style of teachers with Problem Based Learning had a large impact on the reduction of mathematics anxiety in students in all majors of Natural Sciences and Social Sciences, statistically significant $(p<0.05)$ and practically significant with their respective effects (effects) $-d=0.84$ and $d=0.55$, and (2) There is a significant interaction between mathematics content and teacher teaching style in determining the level of mathematics anxiety with significance ( $p$ $<0.05)$.
\end{abstract}

Keywords: teaching style, mathematics anxiety, mathematical content. 


\section{Pendahuluan}

Matematika merupakan mata pelajaran yang sangat berperan dalam mengembangkan kemampuan bernalar dan sangat berguna untuk memecahkan permasalahan sehari-hari. Mengingat pentingnya matematika (Afriansyah, dkk., 2019) tersebut, maka matematika diajarkan mulai dari tingkat sekolah dasar sampai perguruan tinggi. Namun dalam implementasinya di sekolah, tanpa disadari bahwa tuntutan guru dan orang tua agar siswa berprestasi telah menimbulkan kecemasan bagi siswa.

Kecemasan pribadi selalu menjadi penyakit kritis yang secara negatif mempengaruhi kehidupan sosial dan kinerja akademik seseorang pada tingkat rutin, reaktif, dan reflektif (Hashempour \& Mehrad, 2014). Melalui studi literatur diakui bahwa kecemasan berdampak negatif pada kinerja akademik siswa (Uysal \& Dede, 2016; Zakariya, 2018). Penting untuk membedakan antara kecemasan pribadi dan kecemasan matematika. Kecemasan matematika dikaitkan dengan orang-orang yang merasakan ketegangan, ketakutan, ketidaknyamanan, gangguan dan ketakutan akan masalah dan situasi yang melibatkan matematika. Matematika merupakan pelajaran yang tidak banyak disukai orang, yang memancing sikap negatif dan menyebabkan pengalaman kegagalan (Dowker, Sarkar, \& Looi, 2016). Ada banyak faktor yang menyebabkan kegagalan. Salah satu faktor kegagalan adalah adanya kecemasan.
Kecemasan matematika didefinisikan sebagai perasaan khawatir dan peningkatan reaktivitas fisiologis ketika individu berurusan dengan matematika, seperti ketika mereka harus memanipulasi angka, memecahkan masalah matematika, atau ketika mereka dihadapkan pada situasi evaluatif yang terhubung dengan matematika (Luttenberger, Wimmer, \& Paechter, 2018). Lebih luas, kecemasan matematika dapat didefinisikan sebagai stres belajar dalam kelas matematika atau dalam situasi yang membutuhkan matematika atau menghindari dari situasi matematika yang menakutkan (Lai, Zhu, Chen, \& Li, 2015).

Kecemasan matematika pada umumnya bermula dari pengalaman negatif atau memalukan siswa sebelumnya dengan matematika atau seorang guru matematika. Kecemasan matematika bukanlah ketidakmampuan belajar, tetapi itu mengganggu dengan kemampuan individu untuk belajar matematika dan menghambat kemampuan siswa untuk memahami dan berpartisipasi dalam matematika (Lai, dkk., 2015; Passolunghi, Caviola, De Agostini, Perin, \& Mammarella, 2016).

Faktor penyebab kecemasan matematika dapat diklasifikasikan dalam tiga kategori: (1) faktor lingkungan, seperti pengalaman negatif di kelas, tekanan orang tua, guru yang tidak peka, konten matematika, pendidikan matematika konvensional yang disampaikan dengan aturan ketat; (2) faktor mental, seperti 
metode pengajaran yang tidak sesuai dengan gaya belajar, kurangnya tekad siswa, kurangnya kepercayaan diri dalam matematika, keterampilan emisial dan kurangnya kepercayaan pada kegunaan matematika; dan (3) faktor pribadi, seperti keengganan untuk bertanya karena malu, takut dan rendah diri (Krystle, Fitzpatrick, \& Hallett, 2017; Lai, Zhu, Chen, \& Li, 2015).

Hasil penelitian sebelumnya telah mengungkap adanya korelasi negatif yang signifikan antara kecemasan matematika dan konsep diri (Lai, Zhu, Chen, \& Li, 2015b; Mutlu, 2019). Kecemasan matematika yang tinggi akan mengakibatkan siswa menghindari situasi yang membutuhkan matematika, yang mana dapat "menghasilkan lebih sedikit kompetensi, paparan dan praktik matematika, dan meninggalkan kecemasan siswa lebih mendalam (Agus \& Mastika, 2018). Sedangkan Finlayson percaya bahwa perilaku guru adalah faktor utama yang berkontribusi terhadap kecemasan matematika pada diri siswa (Finlayson, 2014).

Penelitian ini dirancang untuk menjawab pertanyaan-pertanyaan berikut: (1) Seberapa besar tingkat kecemasan matematika siswa kelas $X$ pada jurusan IPA dan IPS setelah mengikuti pembelajaran?, (2) Seberapa besar tingkat kecemasan siswa kelas $X$ pada jurusan IPA dan IPS pada konten matematika?, (3) Apakah terdapat dampak gaya mengajar guru pada tingkat kecemasan matematika yang dialami siswa jurusan IPA dan IPS?, dan (4) Apakah terdapat interaksi antara konten matematika dan gaya mengajar guru dalam menentukan tingkat kecemasan matematika siswa?.

\section{Metode}

Penelitian ini menggunakan Ex Post Facto Design yaitu studi quasieksperimental yang meneliti bagaimana variabel independen sebelum dan sesudah penelitian terhadap subjek serta dampaknya terhadap variabel dependen. Sebuah studi quasi-eksperimental ini berarti sampel tidak diambil secara acak (Sharma, 2019).

Jumlah populasi dalam penelitian ini sebanyak 124 siswa kelas X. Melalui teknik random sampling diperoleh 2 kelas yaitu kelas X-IPA1 = 32 siswa, dan X-IPS1 = 32 siswa (lihat tabel 1). Total jumlah anggota populasi adalah 64 responden. kedua kelas tersebut menerima pembelajaran matematika yang diampu oleh guru senior (A) dan guru magang (B). Kelas IPA dan IPS mendapat pembelajaran Problem based Learning (PBL) dan Direct Learning (Pembelajaran Langsung).

Data dikumpulkan selama dua minggu berurutan dari siswa kelas $X$ yang

Tabel 1

Perlakuan Pembelajaran

\begin{tabular}{|cccc|}
\hline Rombel & $\begin{array}{c}\text { Jumlah } \\
\text { Siswa }\end{array}$ & $\begin{array}{c}\text { Perlakuan } \\
\text { Pembelajaran }\end{array}$ & $\begin{array}{c}\text { Guru } \\
\text { Penagmpu }\end{array}$ \\
\hline X-IPA 1 & 32 & Direct Learning & Guru (A) \\
\cline { 3 - 4 } & & PBL & Guru (B) \\
\hline X-IPS 1 & 32 & Direct Learning & Guru (A) \\
\cline { 3 - 4 } & & PBL & Guru (B) \\
\hline Jumlah & 64 & 2 & 2
\end{tabular}


mengikuti pembelajaran matematika di sekolah. Pembelajaran matematika dilakukan oleh dua orang guru secara bergantian. Jumlah siswa yang mengikuti pembelajaran sebanyak 62 siswa (dari 2 kelas). Di awal dan akhir pembelajaran matematika, siswa diminta secara sukarela untuk mengisi angket survei kecemasan matematika yang meliputi aspek kecemasan siswa terhadap konten matematika (8 item) dan kecemasan siswa terhadap gaya mengajar guru (22 item). Data akhir yang diambil hanya data yang berpasangan yaitu sebanyak 60 responden sehingga memungkinkan dilakukan analisis statistik berpasangan. Angket survey berisi 30 item kecemasan matematika dimana siswa merespons pada skala Likert 1-5. Survei meminta siswa untuk mendefinisikan tingkat kecemasan matematika mereka ketika berhadapan dengan situasi sehari-hari dan selama mengikuti pembelajaran matematika.

Konten matematika yang disajikan oleh guru (A dan B) dalam pembelajaran di kelas adalah materi persamaan dan pertidaksamaan linier. Siswa diharuskan untuk bernalar secara matematis, menyelesaikan masalah, dan berkomunikasi matematika secara efektif, menggunakan berbagai representasi konsep dan prosedur matematika. Kedua Guru (A dan B) menggunakan buku teks yang sama dan membahas bab-bab yang sama. Pembelajaran dilaksanakan dua kali per minggu, dan setiap sesi berdurasi 80 menit.
Peneliti mengamati pembelajaran matematika masing-masing ruang kelas di beberapa kesempatan selama dua minggu di awal semester Ganjil tahun pelajaran 2019/2020 untuk mengumpulkan data (setidaknya dua kali per minggu). Selama observasi kelas, peneliti mengambil catatan observasi tentang setting kelas dan gaya mengajar ditunjukkan oleh masing-masing guru ( $A$ dan $B$ ) dan juga mengumpulkan salinan silabus dan penilaian.

Guru A memiliki pengalaman mengajar matematika selama 8 tahun di sekolah. Peneliti mengikuti prosedur yang hampir sama pada setiap pengamatan pembelajaran. Guru A mempresentasikan beberapa contoh di papan tulis, menunjukkan langkah-langkah dalam penyelesaian masalah, memungkinkan waktu untuk pertanyaan, dan kemudian siswa diberi tugas pekerjaan rumah (masalah yang mirip dengan contoh yang disajikan di kelas). Wacana kelas adalah pembelajaran lebih didorong dan didominasi oleh papan tulis dan buku; tidak ada penggunaan alat peraga manipulatif selama pembelajaran diamati. Siswa duduk di kursi mereka, mencatat, dan mengerjakannya sendiri-sendiri masalah yang ditugaskan. Guru A mengatur langkah wacana, dengan fokus yang jelas tentang perhitungan dan keterampilan dalam pengajaran sampai tahap penilaian. Dari catatan pengamatan, jelas bahwa Guru A mengikuti pembelajaran langsung terutama gaya 
mengajarnya. Dalam studi ini, Guru A mengajar disebut memiliki gaya mengajar langsung (Direct Learning).

Guru B adalah guru magang dalam praktik pengalaman mengajar di sekolah. Saat mengajar Guru B sering kali menggunakan variasi bahan fisik dan model presentasi. Siswa didorong untuk aktif, melalui kegiatan eksplorasi, untuk menunjukkan kemauan dan kemampuan siswa untuk menyelesaikan berbagai jenis masalah matematika menggunakan strategi yang sesuai. Siswa diminta untuk menjelaskan jawaban, alasan, dan metode penyelesaian masalah mereka di depan kelas, pada pekerjaan rumah, dan pada penilaian. Pada pembelajaran siswa sering meninggalkan tempat duduknya untuk berdiskusi dan bekerja dengan siswa lain dalam memecahkan masalah, dan membuat presentasi singkat berdasarkan eksplorasi mereka. Siswa sering didorong untuk bekerja berpasangan atau kelompok untuk mengeksplorasi, menemukan, dan menyajikan solusi permasalahan. Itu sebagian besar sesi kelas berisi satu dari lebih dari lima elemen utama Problem Based Learning. Jelas bahwa Guru B mengikuti gaya mengajar yang lebih berbasis masalah dan disebut sebagai gaya mengajar berbasis masalah (Problem Based Learning).

Analisis data angket hanya untuk siswa yang berhasil mengikuti kelas pembelajaran dengan menyelesaikan survei sebelum dan sesudah mengikuti pembelajaran dengan konten matematika.
Untuk menguji normalitas, digunakan uji Kolmogorov-Smirnov (dengan $p>0,05$ ). Data hasil penelitian diolah dengan bantuan SPSS 20.0. Untuk menguji adanya dampak (efek) dari variable bebas terhadap variable terikat dilihat melalui signifikansi praktis, dengan ukuran efek (0 $<d<0,2) ;(0,2 \leq d<0,8)$ dan $(0,8 \leq d)$ masing-masing untuk signifikansi praktis (dampak) kecil, sedang, dan besar. Untuk menguji adanya interaksi antar variable bebas terhadap variable terikat di gunakan uji Anova dua arah dengan interaksi. Sedangkan untuk mengukur tingkat kecemasan matematika digunakan criteria yang telah dikembangkan oleh Cheng (2012) seperti pada Tabel 2.

\section{Hasil dan Pembahasan}

Untuk menjawab pertanyaan penelitian pertama, peneliti telah menguji data secara signifikan membuktikan bahwa data mengikuti distribusi normal. Selanjutnya menentukan rentang, mean ( $\mu)$ standar deviasi $\left(\sigma_{\bar{x}}\right), \quad p$-nilai (signifikansi statistik), dan $d$-nilai (signifikansi praktis) dari kecemasan matematika untuk 90 siswa sebelum dan setelah mengikuti kelas pembelajaran

Tabel 2. Ukuran Tingkat Kecemasan Matematika

\begin{tabular}{cc|}
\hline $\begin{array}{c}\text { Skor Kecemasan } \\
\text { Matematika }\end{array}$ & $\begin{array}{c}\text { Kategori Tingkat } \\
\text { Kecemasan }\end{array}$ \\
\hline $0<\mathrm{MA} \leq 25$ & Rendah \\
\hline $25<\mathrm{MA} \leq 50$ & Sedang (Menengah) \\
\hline $50<\mathrm{MA} \leq 75$ & Tinggi \\
\hline $75<\mathrm{MA} \leq 100$ & Sangat Tinggi \\
\hline & Sumber: (Cheng, 2012) \\
\hline
\end{tabular}


matematika. Data hasil penelitian disajikan pada Tabel 3.

Tabel 3 menunjukkan bahwa siswa sebelum mengikuti kelas pembelajaran matematika memiliki skor kecemasan ratarata 73,7 dan setelah selesai mengikuti pembelajaran skor rata-rata 65,4 atau terjadi penurunan 8,3 poin. Deviasi standar menurun dari 12,94 menjadi 10,8 setelahnya pembelajaran. Tingkat kecemasan memiliki signifikansi secara statistik $(p<0,05)$ dan ukuran signifikansi praktis pada level besar $(d=0,87)$.

Pertanyaan penelitian kedua, dijawab melalui data kecemasan siswa terhadap konten matematika. Data diambil melalui angket tentang pendapat siswa terhadap konten (materi) matematika. Angket disusun dalam bentuk pernyataan dengan 8 indikator. Instrumen kecemasan terhadap konten matematika dikembangkan dari hasil penelitian sebelumnya yang memiliki tingkat validitas dan reliabilitas tinggi sebagai instrument penelitian (Shehayeb, 2018; Shehayeb \& Anouti, 2018).

Memperhatikan Tabel 4, hasil angket kecemasan siswa terhadap konten matematika dari kedua jurusan IPA dan IPS berada pada tingkat kecemasan yang tinggi. Tingkat kecemasan siswa IPA sebesar 71,25 dan IPS sebesar 75,57 hanya terpaut perbedaan sebesar 4,32 poin. Sebagian besar siswa jurusan IPS menganggap bahwa konten (materi) matematika masuk kategori yang sulit. Sedangkan secara populasi kecemasan siswa terhadap konten matematika sebesar 72,69 (kecemasan tinggi). Bahkan 76\% siswa menganggap bahwa materi matematika tiap tahun semakin sulit, dan $43 \%$ siswa merasakan pusing saat menghadapi materi matematika yang sulit. Sehingga, setiap membuka buku pelajaran matematika, siswa selalu cemas menghadapi pelajaran matematika. Terkadang mereka saat dijelaskan materi pelajaran di kelas telah paham, namun jika

Tabel 3.

Kecemasan matematika sebelum dan sesudah pembelajaran

\begin{tabular}{lcccccccccc}
\hline & \multicolumn{4}{c}{ Sebelum Pembelajaran } & \multicolumn{4}{c}{ Sesudah Pembelajaran } \\
\hline & $N$ & Range & $\mu$ & $\sigma_{\bar{x}}$ & Range & $\mu$ & $\sigma_{\bar{x}}$ & $\begin{array}{c}p \text { - } \\
\text { value }\end{array}$ & $d$-value \\
\hline $\begin{array}{l}\text { Partisipasi } \\
\text { Siswa }\end{array}$ & 60 & $72-125$ & 73.7 & 12.94 & $49-110$ & 65.4 & 10.8 & 0.000 & 0.87 \\
\hline
\end{tabular}

Tabel 4.

Deskripsi Statistik Kecemasan Siswa terhadap Konten Matematika

\begin{tabular}{lcccccc}
\hline $\begin{array}{l}\text { Rombongan } \\
\text { Belajar }\end{array}$ & $N$ & Range & $\begin{array}{c}\text { Mean } \\
\mu\end{array}$ & $\begin{array}{c}\text { Std. } \\
\text { Deviation }\end{array}$ & Variance & $\begin{array}{l}\text { Tingkat } \\
\text { Kecemasan }\end{array}$ \\
\hline Jurusan_IPA & 30 & $22-35$ & 28.5000 & 3.62898 & 13.169 & 71.25 \\
\hline Jurusan_IPS & 30 & $24-36$ & 30.2333 & 3.21294 & 10.323 & 75.57 \\
\hline Total Siswa & 60 & $22-36$ & 29.0766 & 3.48984 & 12.2203 & 72.69 \\
\hline
\end{tabular}


belajar sendiri di rumah menjadi "blank" kosong dan kembali tidak paham.

Untuk menjawab pertanyaan penelitian ketiga tentang dampak gaya mengajar, peneliti membandingkan siswa yang mengikuti pembelajaran langsung (Direct Learning) oleh guru A dengan siswa yang mengikuti pembelajaran Problem Based Learning (PBL) oleh Guru B. Peneliti menyelidiki adanya perbedaan tingkat kecemasan antara sebelum dan sesudah pembelajaran dengan signifikan secara statistik $(p<0,050)$, peneliti juga menyelidiki ukuran signifikansi secara praktis (efek) (lihat Tabel 5).

Perbandingan skor rata-rata kecemasan sebelum mengikuti pembelajaran menunjukkan bahwa siswa di kelas Direct learning dimulai dengan kecemasan yang lebih tinggi daripada siswa di kelas PBL. Uji Mann-Whitney membandingkan gaya mengajar dengan Direct Learning dan PBL siswa sebelum dan sesudah pembelajaran menunjukkan bahwa ada perbedaan yang signifikan secara statistik $(p=0,000)$. Penurunan tajam tingkat kecemasan ditunjukkan pada Tabel 5 untuk populasi PBL yaitu sebesar 11,60 poin dengan dampak yang besar $(d=1,47)$. Sedangkan pembelajaran degan gaya mengajar Direct Learning tidak ada dampaknya. Mungkin karena populasi Direct Learning dimulai

Tabel 5.

Dampak Gaya Mengajar Guru terhadap Tingkat Kecemasan Matematika Sebelum Pembelajaran Sesudah Pembelajaran

\begin{tabular}{lccccccccccc}
\hline $\begin{array}{c}\text { Gaya } \\
\text { Mengajar }\end{array}$ & $N$ & Range & $\mu$ & $\sigma_{\bar{x}}$ & Range & $\mu$ & $\sigma_{\bar{x}}$ & $\begin{array}{c}\text { Impact } \\
\text { Points }\end{array}$ & $\begin{array}{c}p- \\
\text { value }\end{array}$ & $\begin{array}{c}d- \\
\text { value }\end{array}$ \\
\hline PBL & 30 & $46-107$ & 73.8 & 13.46 & $49-88$ & $\begin{array}{c}62 \\
2\end{array}$ & $\begin{array}{c}11 . \\
8\end{array}$ & -11.60 & 0.000 & 1.47 \\
\hline $\begin{array}{l}\text { Direct. } \\
\text { Learning }\end{array}$ & 30 & $66-102$ & 84.3 & 11.34 & $55-99$ & $\begin{array}{c}84 . \\
6\end{array}$ & $\begin{array}{c}12 . \\
3\end{array}$ & +0.30 & 0.145 & - \\
\hline
\end{tabular}

Tabel 6.

Dampak Gaya Mengajar Guru terhadap Kecemasan Matematika

\begin{tabular}{|c|c|c|c|c|c|c|c|c|c|c|}
\hline \multirow[t]{2}{*}{$\begin{array}{c}\text { Gaya } \\
\text { Mengajar }\end{array}$} & \multicolumn{4}{|c|}{ Sebelum Pembelajaran } & \multicolumn{3}{|c|}{$\begin{array}{c}\text { Sesudah } \\
\text { Pembelajaran }\end{array}$} & \multirow[t]{2}{*}{$\begin{array}{l}\text { Impact } \\
\text { Points }\end{array}$} & \multirow[t]{2}{*}{$\begin{array}{c}p- \\
\text { value }\end{array}$} & \multirow[t]{2}{*}{$\begin{array}{c}d- \\
\text { value }\end{array}$} \\
\hline & $N$ & Range & $\mu$ & $\sigma_{\bar{x}}$ & Range & $\mu$ & $\sigma_{\bar{x}}$ & & & \\
\hline \multicolumn{11}{|l|}{ PBL } \\
\hline IPA & 30 & $63-107$ & 77.5 & 7.26 & $53-88$ & $\begin{array}{c}70 . \\
9\end{array}$ & $\begin{array}{c}12 . \\
4\end{array}$ & -6.60 & 0.006 & 0.84 \\
\hline IPS & 30 & $68-102$ & 80.3 & 12.30 & $63-99$ & $\begin{array}{c}78 . \\
6 \\
\end{array}$ & $\begin{array}{c}11 . \\
8 \\
\end{array}$ & -2.70 & 0.000 & 0.55 \\
\hline \multicolumn{11}{|l|}{ Direct.L } \\
\hline IPA & 30 & $46-99$ & 70.1 & 9.04 & $\begin{array}{l}49- \\
106 \\
\end{array}$ & $\begin{array}{c}53 . \\
5 \\
\end{array}$ & $\begin{array}{c}8.3 \\
5 \\
\end{array}$ & -16.60 & 0.000 & 1.87 \\
\hline PS & 30 & $66-94$ & 88.3 & 13.51 & $55-88$ & $\begin{array}{c}90 . \\
6\end{array}$ & $\begin{array}{c}13 . \\
6\end{array}$ & +2.60 & 0.324 & -- \\
\hline
\end{tabular}


dengan kecemasan yang jauh lebih tinggi, sehingga tidak mudah untuk menurunkan kecemasan siswa dengan kecemasan tinggi.

Selanjutnya, untuk menyelidiki adanya dampak (efek) variabel bebas (gaya mengajar guru) terhadap variabel terikat (kecemasan matematika) sesuai jurusan disajikan data hasil penelitian pada Tabel 6.

Hasil untuk total populasi menunjukkan bahwa kelas IPA diuntungkan dengan mengikuti kedua pembelajaran karena signifikan secara statistic $(p<0,05)$. Perbedaan yang lebih signifikan oleh jurusan IPA dan IPS terlihat besar ketika ditinjau dari gaya mengajar. Gaya mengajar guru A (PBL) memiliki dampak yang besar pada penurunan kecemasan siswa pada jurusan IPA dan IPS, yang secara statistik signifikan $(p<0,05)$ dan secara praktis dengan ukuran dampak (efek) masing-masing $d=0,84$ dan $d=$ 0,55 . Sedangkan, gaya mengajar guru $B$
(Direct Learning) hanya memberikan dampak kepada siswa kelas

IPA saja yang menunjukkan penurunan kecemasan terbesar $(16,60$ poin) dengan signifikan secara statistik $(p<0,05)$ dan secara praktis dengan ukuran dampak (efek) besar yaitu $d=1.87$.

Pertanyaan penelitian keempat, apakah terdapat interaksi antara konten matematika dan gaya mengajar guru dalam penentuan tingkat kecemasan matematika siswa? Pertanyaan dijawab dengan analisis melalui Uji Anova dua arah pada Tabel 7 dan Gambar 1.

Pada Tabel 6 menunjukkan bahwa taraf Sig. $0,031<0,05$, mengakibatkan $\mathrm{Ho}$ ditolak. Sehingga disimpulkan terdapat interaksi yang berarti antara konten matematika dan gaya mengajar guru dalam menentukan tingkat kecemasan matematika siswa. Hubungan adanya interaksi antara konten matematika dan gaya mengajar dalam menentukan tingkat kecemasan matematika juga diperkuat dengan ditunjukkan melalui Gambar 1.

Tabel 7

Interaksi Konten Matematika dan Gaya Mengajar

Tests of Between-Subjects Effects

Dependent Variable: Kecemasan

\begin{tabular}{lrrrrr}
\hline Source & $\begin{array}{c}\text { Type III Sum of } \\
\text { Squares }\end{array}$ & df & Mean Square & F & Sig. \\
\hline Corrected Model & $2027.481^{\text {a }}$ & 5 & 405.496 & 2.384 & .045 \\
Intercept & 278648.310 & 1 & 278648.310 & 1638.533 & .000 \\
Konten & 1277.178 & 2 & 638.589 & 3.755 & .027 \\
Gaya Mengajar & 369.783 & 1 & 369.783 & 2.174 & .144 \\
Konten * Gaya Mengajar & 1231.122 & 2 & 615.561 & 3.620 & .031 \\
Error & 14285.007 & 84 & 170.060 & & \\
Total & 489520.000 & 90 & & & \\
Corrected Total & 16312.489 & 89 & & & \\
\hline
\end{tabular}

a. R Squared $=.124$ (Adjusted R Squared $=.072$ ) 
Gambar 1 memperlihatkan adanya interaksi karena adanya perpotongan garis yang ditunjukkan oleh grafik di atas. Pada siswa jurusan IPS, bagaimanapun konten matematika yang diajarkan oleh guru baik melalui PBL ataupun Direct Learning, para siswa pada jurusan IPS masalah konten matematika tetap terasa berat dan sulit. Sehingga interaksi antara konten matematika dan gaya mengajar guru menjadi faktor penentu tingkat kecemasan matematika pada siswa. Sedangkan siswa jurusan IPA memandang bahwa konten matematika baik diajarkan melalui PBL maupun Direct Learning masih lebih mudah atau menimbulkan kecemasan matematika yang lebih rendah dari jurusan IPS. Dengan kata lain, interaksi antara konten matematika dan gaya mengajar guru menjadi faktor penentu tingkat kecemasan matematika siswa jurusan IPA, namun tidak setinggi pada siswa jurusan IPS.

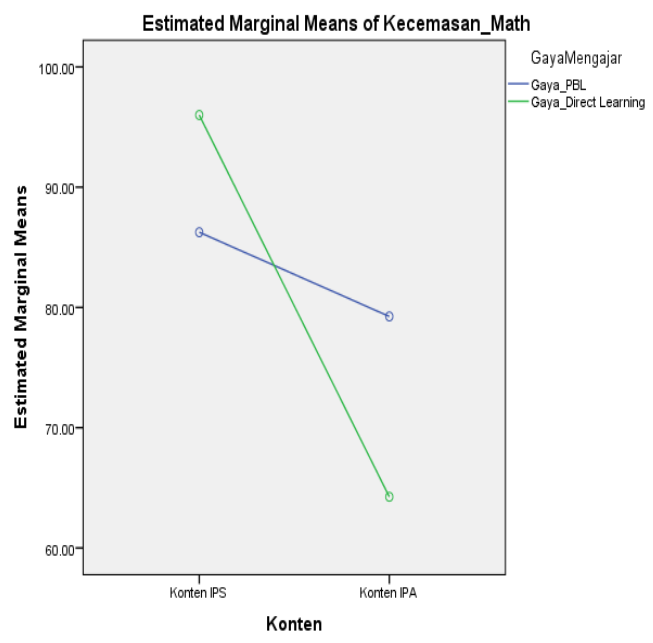

Gambar 1. Interaksi Gaya Mengajar dan Konten Matematika.
Peneliti setuju dengan pendapat Waru (2016) bahwa gaya mengajar guru dengan pembelajaran Direct Learning (pembelajaran langsung) jarang efektif untuk semua siswa. Namun, dalam penelitian ini, gaya mengajar guru dengan pembelajaran $\mathrm{PBL}$ sangat signifikan mengurangi kecemasan matematika dalam pembelajaran matematika di sekolah. Karena pembelajaran menggunakan PBL menunjukkan kecemasan matematika lebih rendah dari pembelajaran Direct Learning dan karenanya juga meningkatkan keterampilan matematika.

Luasnya praktik sosial mengajar guru dan aspek kognitif, sejalan dengan pendapat Hader (2017), adalah faktor kuat yang berkontribusi pada siswa kecemasan matematika yang menunjukkan bahwa pengalaman mengajar saja tidak cukup untuk guru yang sukses kecuali diberlakukan dengan mengikuti pelatihan dan workshop pendidikan. Para guru perlu mengetahui bagaimana bertindak dengan siswa mereka, mengajar mereka dengan baik, inovatif dan kreatif dan menegakkan pembelajaran mereka untuk lingkungan belajar yang cocok dan kinerja akademik yang lebih baik.

Sedangkan konten matematika, bagaimanapun konten matematika yang diajarkan oleh guru, bagi para siswa pada jurusan IPS hal ini tetap terasa berat dari pada anggapan siswa jurusan IPA. Selain itu, terkadang siswa jurusan IPS merasa cemas ketika guru mereka bekerja keras 
untuk tumbuhnya kemampuan mereka berpikir kritis namun tidak diimbangi dengan umpan balik terhadap kinerja siswa. Mereka (para siswa) lebih membutuhkan bagaimana guru mengajar dengan baik dan membantu kesulitan mereka. Oleh karena itu, sependapat dengan Ridia dan Afriansyah (2019), guru sebagai fasilitator pembelajaran bertanggung jawab untuk memastikan bahwa dalam pembelajaran tidak terjadi kondisi kecemasan matematika melalui penerapan pembelajaran yang kreatif, inovatif dan menciptakan interaksi sosial yang kondusif.

\section{Penutup}

Kesimpulan dari penelitian ini adalah (1) Tingkat kecemasan matematika pada siswa kelas $X$ jurusan IPA dan IPS setelah mengikuti pembelajaran berada pada tingkat kecemasan tinggi yaitu mencapai 65,4 , (2) Tingkat kecemasan siswa pada konten matematika sebesar 72,69 (kecemasan tinggi), (3) Gaya mengajar guru dengan PBL memiliki dampak yang besar pada penurunan kecemasan matematika pada siswa di semua jurusan IPA dan IPS, signifikan secara statistik ( $p<$ $0,05)$ dan secara praktis dengan ukuran dampak (efek) masing-masing $d=0,84$ dan $d=0,55$. Sedangkan, gaya mengajar guru dengan Direct Learning hanya memberikan dampak kepada siswa jurusan IPA saja dengan penurunan kecemasan terbesar (16,60 poin), signifikan secara statistik ( $p<$ $0,05)$ dan secara praktis dengan ukuran dampak (efek) besar yaitu $d=1.87$.dan (4) Terdapat interaksi yang kuat antara konten matematika dan gaya mengajar guru dalam menentukan tingkat kecemasan matematika siswa dengan taraf signifikasi $(p<0,05)$.

\section{UCAPAN TERIMA KASIH}

Ucapan terima kasih disampaikan kepada LPPM Universitas Islam Sultan Agung yang telah mendanai penelitian ini. Tak lupa diucapkan terima kasih kepada para dosen dan mahasiswa yang membantu proses penelitian ini.

\section{Daftar PUstaka}

Afriansyah, E. A., Puspitasari, N., Luritawaty, I. P., Mardiani, D., \& Sundayana, R. (2019). The analysis of mathematics with ATLAS.ti. Journal of Physics: Conference Series 1402(7), 077097.

Agus, P., \& Mastika, E. (2018). Kecemasan Matematika Pada Mahasiswa Pendidikan Guru Sekolah Dasar. Journal of Education Technology, 2(2), 36-45.

Cheng, Y. S. (2012). A measure of second language writing anxiety: Scale development and preliminary validation. Journal of Second Language Writing, 13(4), 313-335. https://doi.org/10.1016/j.jslw.2004.0 7.001

Dowker, A., Sarkar, A., \& Looi, C. Y. (2016). Mathematics anxiety: What have we learned in 60 years? Frontiers in 
Psychology,

7(APR).

https://doi.org/10.3389/fpsyg.2016.0 0508

Finlayson, M. (2014). Addressing math anxiety in the classroom. Improving Schools, 17(1), 99-115. https://doi.org/doi:10.1177/1365480 $\underline{214521457}$

Hader, A. E. (2017). Pengaruh Penerapan Model Pembelajaran Student Facilitator And Explaining pada Mata Kuliah Pendidikan Matematika Anak Usia Dini terhadap Keaktifan Mahasiswa Program Studi PGPAUD Universitas Dharmas Indonesia. Mosharafa: Jurnal Pendidikan Matematika, 6(2), 305-310. DOI: https://doi.org/10.31980/mosha rafa.v6i2.319

Hashempour, S., \& Mehrad, A. (2014). The effect of anxiety and emotional intelligence on students ' learning process faculty of human ecology. Journal of Education \& Social Policy, 1(2), 115-122.

Krystle, O., Fitzpatrick, C. L., \& Hallett, D. (2017). Math Anxiety Is Related to Some, but Not All, Experiences with Math. Frontiers in Psychology, 8(2067), 129-142.

Lai, Y., Zhu, X., Chen, Y., \& Li, Y. (2015a). Effects of mathematics anxiety and mathematical metacognition on word problem solving in children with and without mathematical learning difficulties. PLOS ONE, 10(6), 1-19. https://doi.org/10.1371/journal.pone
.0130570

Lai, Y., Zhu, X., Chen, Y., \& Li, Y. (2015b). Effects of Mathematics Anxiety and Mathematical Metacognition on Word Problem Solving in Children with and without Mathematical Learning Difficulties. PLOS ONE Journal, 6(6), 1-19. https://doi.org/10.1371/journal.pone .0130570

Luttenberger, S., Wimmer, S., \& Paechter, M. (2018). Spotlight on math anxiety. Psychology Research and Behavior Management, 11(1), 311-322. https://doi.org/10.2147/PRBM.S1414 21

Mutlu, Y. (2019). Math Anxiety in Students With and Without Math Learning Difficulties. International Electronic Journal of Elementary Education, 11(5), 471-475. https://doi.org/10.26822/iejee.20195 53343

Passolunghi, M. C., Caviola, S., De Agostini, R., Perin, C., \& Mammarella, I. C. (2016). Mathematics anxiety, working memory, and mathematics performance in secondary-school children. Frontiers in Psychology, 7(2), 1-8.

https://doi.org/10.3389/fpsyg.2016.0 0042

Ridia, N. S., \& Afriansyah, E. A. (2019). Perbandingan Kemampuan Pemahaman Matematis Siswa melalui Auditory Intellectualy Repetition dan Student Teams Achievement Division. 
Mosharafa: Jurnal Pendidikan Matematika, 8(3), 515-526. DOI: https://doi.org/10.31980/mosha $\underline{\text { rafa.v8i3.509 }}$

Sharma, S. (2019). Experimental and Ex Post Facto Designs. In Horizon University (Vol. May, pp. 1-17). Horizon University. Retrieved from https://www.researchgate.net/public ation/333220493_Experimental_and _Ex_Post_Facto_Designs\#pf9

Shehayeb, S. (2018). Journal of Depression and Anxiety s Practices and Content of Mathematics on The Impact of Teacher' s Student' Anxiety in Secondary and Intermediate Classes. Journal of Depression and Anxiety, 7(4), $1-8$.

https://doi.org/10.4172/2167-

1044.1000320

Shehayeb, S., \& Anouti, M. (2018). The Impact of Teacher's Practices and Content of Mathematics on Student's Anxiety in Secondary and Intermediate Classes. Journal of Depression and Anxiety, 7(4), 1-8. https://doi.org/10.4172/21671044.1000320

Uysal, F., \& Dede, Y. (2016). Mathematics Anxiety and Beliefs of Turkish Preservice Elementary Teachers. EURASIA Journal of Mathematics, Science \& Technology Education, 12(8), 2171-2186. https://doi.org/10.12973/eurasia.201 $\underline{6.1418 \mathrm{a}}$

Waru, M. V. (2016). Perbandingan
Kemampuan Komunikasi Matematika melalui Pembelajaran Quantum dan Pembelajaran Langsung dengan Memperhitungkan Kemampuan Awal Siswa. Mosharafa: Jurnal Pendidikan Matematika, 5(2), 93-100. DOI: https://doi.org/10.31980/mosha rafa.v5i2.264

Zakariya, Y. F. (2018). Development of Mathematics Anxiety Scale: Factor Analysis as a Determinant of Subcategories. Journal of Pedagogical Research, 2(2), 135-144.

\section{Riwayat Hidup Penulis} Imam Kusmaryono, S.Pd., M.Pd.

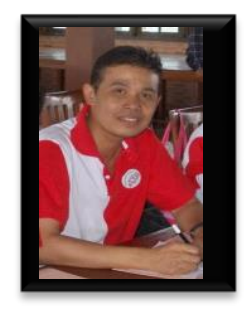

Lahir di Semarang, 26 Maret 1970. Staf pengajar di Program Studi Pendidikan Matematika, Fakultas Keguruan dan Ilmu Pendidikan, Universitas Islam Sultan Agung (UNISSULA) Semarang. Pendidikan S2 Lulus 2008 di UNNES bidang Pendidikan Matematika. Saat ini sedang menempuh program Doktor bidang Pendidikan Matematika di UNNES. Aktif menulis buku dan artikel di jurnal Nasional dan Internasional.

\section{Nuhyal Ulia, S.Pd., M.Pd.}

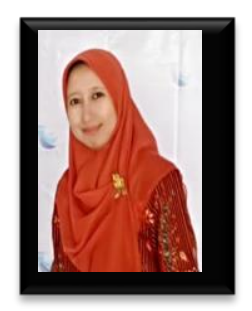

Lahir di Kudus, 22 Desember 1985. Tenaga pengajar di Program Studi Pendidikan Guru Sekolah Dasar FKIP UNISSULA yang memiliki semangat tinggi dalam berkarya. Pendidikan S2 Lulus 2012 di UNNES bidang Pendidikan Matematika. Saat ini menjabat sebagai Ketua Program Studi PGSD di FKIP UNISSULA. Aktif dalam bidang penelitian dan pengabdian masyarakat. 